\title{
The journey of Arabic human rights testimonies, from witnesses to audiences via Amnesty International
}

Nancy Hawker

University of Oxford

\begin{abstract}
Within the human rights knowledge production infrastructure, information undergoes processes of entextualisation, archiving, publication, and reception. This article examines the place of testimonies - first-person accounts of suffering and/or historic events in Amnesty International. A network of agents form around testimonies to produce them through translation from the witnesses' languages - spoken varieties of Arabic - to the language of globalised governance - written English - and to formal written Arabic. The coconstruction of meaning, in encounters between human rights researchers and witnesses, is a modern ritual that is entextualised in the genre 'testimony'; its translations between spoken and written modes, languages and styles, are exercises in persuasive rhetoric aimed at redressing 'testimonial injustice'. The researchers are not professional translators, yet their unselfconscious translations are constitutive of the knowledge that audiences receive. The data is based on interviews and questionnaires with Amnesty International staff, textual analysis of publications, and on focus groups and surveys.
\end{abstract}

Keywords: sociology of translation, Arabic, testimony, human rights, linguistic anthropology, NGOs, epistemic justice, networks of production

\section{Introduction: Networks of agents performing rituals and translations ${ }^{1}$}

\footnotetext{
${ }^{1}$ I would like to thank current and former members of staff at the International Secretariat of Amnesty International, who shared their insights with me in interviews and in the review of an early draft of this article. I would like to express deep gratitude to participants in the focus groups and respondents in the survey who gave serious consideration to questions raised by the research. I enjoyed discussions of these questions with colleagues in the Language and Society group at the University of Oxford led by Professor Deborah Cameron. Dr Wine Tesseur supported my venture into translation studies with patient pedagogic guidance: thank you. The
} 
Testimonies - witness accounts of violence, suffering and/or historic events presented in the first person - are important in journalistic, oral history, literary, human rights, humanitarian and legal work (Spiessens \& Toremans 2016). One of the campaigning aims of human rights organisations in particular is to redress 'testimonial injustice' (Fricker 2007), whereby the accounts of certain witnesses, found at the intersection of subaltern social categorisations, are suppressed (Spivak 1988). Amnesty International has made this aim explicit, in ethical terms, by working to add its authority and credibility (which it earns, conversely, by promoting this work) to the testimonial voices of those whose suffering would otherwise not be heard (Hopgood 2006: 12; Fricker 2007: 130-145). This is visually represented in branding by the megaphone (Vestergaard 2008). ${ }^{2}$ This article figuratively disassembles that megaphone; that is, it examines how testimonies are collected, entextualised, archived, published, and received, as specifically as possible, and with attention to the linguistic permutations of each stage, which involve translation in several senses. The particular case studied is the place of testimonies in the recent work of Amnesty International's Middle East and North Africa (MENA) Programme.

Looking at Amnesty International's internal 'causal chain' (Chesterman 2014: 21) that combines agents and structures to produce knowledge from the angle of the sociology of translation (Koskinen 2010: 181-184) allows this article to give place of honour to a type of text while conceptualising a formative network of agents created around it. Though part of that network involves professional or designated translators (examined in Tesseur 2015), prior to that stage in a text's trajectory translations are done by researchers with multilingual skills whose epistemic task is rhetorical persuasion in the interest of human rights. The case of Arabic testimonies brings the power inflections of those unselfconscious translations to the fore: the researchers conduct human rights fieldwork in a spoken variety of Arabic, and publish their findings in written English, the language of global governance (Crystal 2003: 86-119). The linguistic-anthropological tool 'genre' (Briggs \& Bauman 1992) helps unpick the power dimensions of the testimonial encounter (the researchers' interview of a witness) and its text: a genre arises from a ritual which it represents and also defines in textual form. Once in this form, it can accomplish various discursive functions while remaining recognisably bounded in its textual unit. I conceive of the human rights interview as a modern

research was financed by The Leverhulme Trust with Early Career Fellowship ECF-2013-624. All mistakes and debts are mine.

${ }^{2}$ See the megaphone graphics on 'How change happens' at https://www.amnesty.org/en/what-we-do/, accessed 14 December 2017. 
ritualised event (its historical roots are not examined here; see Jensen \& Jolly 2014) and of the testimony as its genre; throughout the discursive functions that the testimony is put to (from challenging governments to affecting engaged readers), it calls to mind the performance of the witness interview ritual.

The testimony's textual form is that of reported speech (not of any speech, however: it is traumatic narrative (Andrews 2014)), which contains the tension between the control of the 'reporter' (the researcher) and the authority of the 'speaker' (the witness) over the words. Amnesty International's writing guidance to its researchers contradicts itself: 'Let people tell their stories in their own words' (Amnesty International 2017: 24) and 'Imagine you are telling their story to a friend' (ibid.: 28). The contradiction is resolved when the testimonial encounter is viewed as a ritual where agents performing power-inflected roles jointly produce meaning. The ritual is spoken, but the co-produced meaning is written (in the genre that the ritual binds the agents to); writing, which has to minimise ambiguity in order to communicate with a distant reader, is subject to different norms from speaking, which relies on shared contextual knowledge and interactional repair for speaker and interlocutor to understand each other (Milroy \& Milroy 1985: 61-63). Due to the norms of diglossia (Eisele 2002), beliefs about the functions both of strict standardisation in written Modern Standard Arabic (MSA) and of supposedly unwritable extreme variability in spoken Arabics are emphasised in native language intuitions and in some expert traditions, including translation training. This delimitation of Arabic varieties' functions poses a problem for the conveyance of Arabic testimonies in particular: modified spoken varieties of Arabic are transcribed for writing in social media, in reported speech in novels, and on some political placards (Albirini 2016: 932), but not, currently, in human rights reports. To understand how this problem is addressed in Amnesty International's documents, the article will compare the styles of corresponding English and Arabic texts.

The research employed structured interviews conducted in 2016-17 with nine employees of Amnesty International's International Secretariat, each lasting between 45 and 75 minutes, and questionnaires distributed in MENA Programme offices in 2016 and 2017, to collect information on internal linguistic practices and attitudes to these practices. Amnesty International documents were subjected to textual analysis. The research subsequently (201718) utilised focus groups and an experimental online survey with Arab participants in order to investigate audience reactions to Arabic human rights testimonies. The sections of the article are built around the trajectory of a testimony as it passes through the network of agents that 
co-produce it, give it textual forms, and receive it: starting with collection, after that dealing with entextualisation, archiving, publication, professional translation, and reception. The conclusion brings together salient points raised along the way regarding testimonial justice and translation. The purpose is two-fold: to show, first, how translations - including those undertaken by agents whose professional task is not primarily translation - form the epistemic world, and second, how the mediation of testimonies in particular forms agentic networks as a strategy for achieving epistemic justice. The goal of this strategy is to ethically socialise individuals and institutions into including testimonies in the available range of human knowledge without prejudice (Fricker 2007: 176).

\section{Collecting testimonies: notations in a meaning-producing event}

The analysis of this section and the next - on the collecting, entextualising and archiving of testimonies - is based on six interviews conducted in 2016-17 with researchers in the International Secretariat's MENA Programme and on one interview with a senior member in the department responsible for supporting the quality of research. I worked in the Middle East and North Africa Programme from July 2008 to April 2014. Memories of observations of practices, including my own fieldwork, note-taking and document writing, corroborate statements given in the research interviews, but are not analysed explicitly, hence I do not list 'participant observation' as one of the research methods.

These interviews gathered information on the researchers' practices in conducting fieldwork, their perceptions of conditions for producing a testimony, and their attitudes to the significance of testimonies. The MENA Programme interviewees are notated INT1, INT2, etc.; with INT1 representing the researcher who had most recently joined the Programme and INT6, who had undertaken some 30 field research missions, the one with the longest experience. Three of them were native Arabic and three were native English speakers, all with high levels of multilingual proficiency; three continued to serve in the Programme after the organisational restructuring that saw the opening of offices in Beirut, Jerusalem and Tunis in early 2017, and three left the Programme around that time. ${ }^{3}$ All of them had produced reports, campaigning materials and media outputs in English in collaboration with specialised legal, thematic and editorial teams at the International Secretariat. Relying on their language

\footnotetext{
3 'To serve' and 'service' are terms used advisedly in this article for describing work in the International Secretariat, in order to capture the ethos of sacrifice to a cause which, while perhaps not matching the individual experiences of staff members, does ideologically permeate the production of publications and their campaigning uses (Hopgood 2006: 15-21; and see Amnesty International's self-description of the International Secretariat as 'supporting and maintaining systems required to ensure that AI is ready to serve 24 hours a day' on https://www.amnesty.org/en/about-us/how-were-run/structure-and-people/, accessed 14 December 2017).
} 
skills, they had researched armed conflicts in the MENA region, systematic violations of human rights, and longstanding individual cases. The interviewee from the Research and Practice Unit is notated as interviewee INTRes and also had extensive fieldwork and publication-writing experience, having undertaken at least 50 research missions. This interview related to the same questions while seeking more general patterns of practices and attitudes than those applicable to MENA.

In order to have access to truthful and useful evidence, the researchers reported that they initiated field interviews by referring to relevant contextual information, such as the health of the witness (INT3 and INT4). They let the witness lead with their narrative while supporting with paralinguistic expressions, with the aim of making the witness comfortable by showing empathy (INT2 and INT3), before asking focused questions (INT1, INT3, INT5 and INT6). All the researchers understood the encounters with the witnesses to be more than an information-gathering exercise: it was a site where witnesses spoke and were heard by the researchers who represented an institution. This site, if handled well, could in itself uphold the witnesses' human dignity; and in a climate where human rights gains are rare, this (perhaps minimal and fleeting) sense of dignity might be all that Amnesty International could hope to concretely provide to the witnesses (INT2). For several researchers, their respect for the witnesses were conveyed to me as unscripted memories of humanising details which were not relevant to the human rights violation, such as, '[the witness] wanted to save her wedding dress in the escape' (INT2); '[the witnesses] were ordinary guys, carpenters, metalworkers and street cleaners, and they were willing to take on the whole government and security apparatus' (INT5); '[the witness] was a single mother, it was quite hard for her to get by' (INT4).

The encounters between witnesses and researchers were logged in the researchers' field mission notebooks along with records of other types of meetings. The notebooks were issued to researchers for fieldwork purposes, but while the rest of the equipment was returned to the office after use, the fate of the notebooks was not uniform: some researchers kept it in their own possession as 'a memorial' to their service (INT3), some shredded it after inputting all information into digital files (INT6), some filed it in the institutional archive after making a selective record of its contents (INT4 and INT5), and some scanned every page as images onto system folders before filing it away (INT1; more will be said about the purpose of archiving below). 


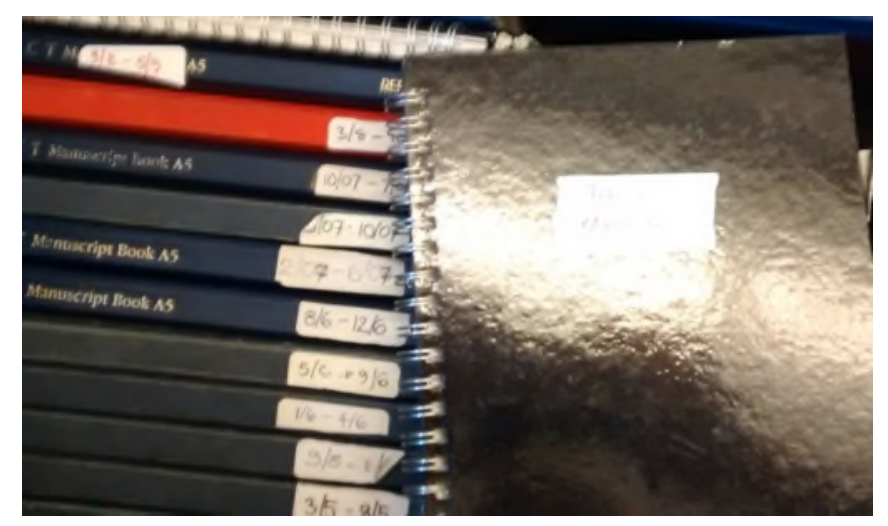

Figure 1 Amnesty International mission notebooks ready for filing (all photographs $(\mathrm{C}$ the author).

The content of the notebooks was more or less the same: they contained dates, names (sometimes in codes for the security of the witness (INT1)), places, and variable quantities and forms of details on these facts, and expressions that captured the witnesses' sentiments. The language of notation differed, though in all cases examined the language of the encounter itself had been a spoken variety of Arabic. One native Arabic speaker took notes in English (INT4) and all researchers, including native English speakers, took at least some notes in Arabic, mostly in Arabic script but sometimes in Latinised transcription (INT5), and in one case using the support of an interpreter (INT2). The only consistent patterns for Arabic notation was the record of the spelling of proper names, the exact terminology of laws, official pronouncements and titles (for instance in the military hierarchy) and local expressions for specific activities (for instance torture techniques).

Withdrawal, numbness and obsessive searching for facts, devised as psychological coping strategies, are within the expected range of reactions to receiving a testimony (Felman \& Laub 1992: 72-3). Obsessive searching for facts was, to some extent, institutionally useful for Amnesty International (INTRes), interpreted by the researchers themselves as 'inquisitiveness' (INT6) and 'forensic skills' (INT3). On certain pages, the notebooks were marked with connecting arrows, highlighted passages, sketches and maps, and lines dividing the page into areas where parallel information, often in idiosyncratic abbreviations, was inserted next to the testimony (INT3, INT5 and INT6). Other pages of the same notebook, and other notebooks in their entirety, presented headings, subheadings, and longhand writing in paragraphs (INT1, INT2 and INT4). Upon revision of the notes, numbering was added next to specific elements to indicate their chronological order (INT1 and INT5). 
Some degree of withdrawal was also evident in the notebooks. Using no personal pronouns when referring to the witness (INT3), or using the $3^{\text {rd }}$ person (INT4 and INT5), was the norm, explained as a means for the researchers to distance themselves from the testimonies, since 'otherwise [the texts read as if] everything was happening to me' (INT4). In pressured situations, such as having limited time to gather information in an overcrowded refugee camp with a queue of willing witnesses forming, the handwriting could become illegible even to the researcher whose attention had withdrawn from the research purpose of fieldwork notation (INT5).

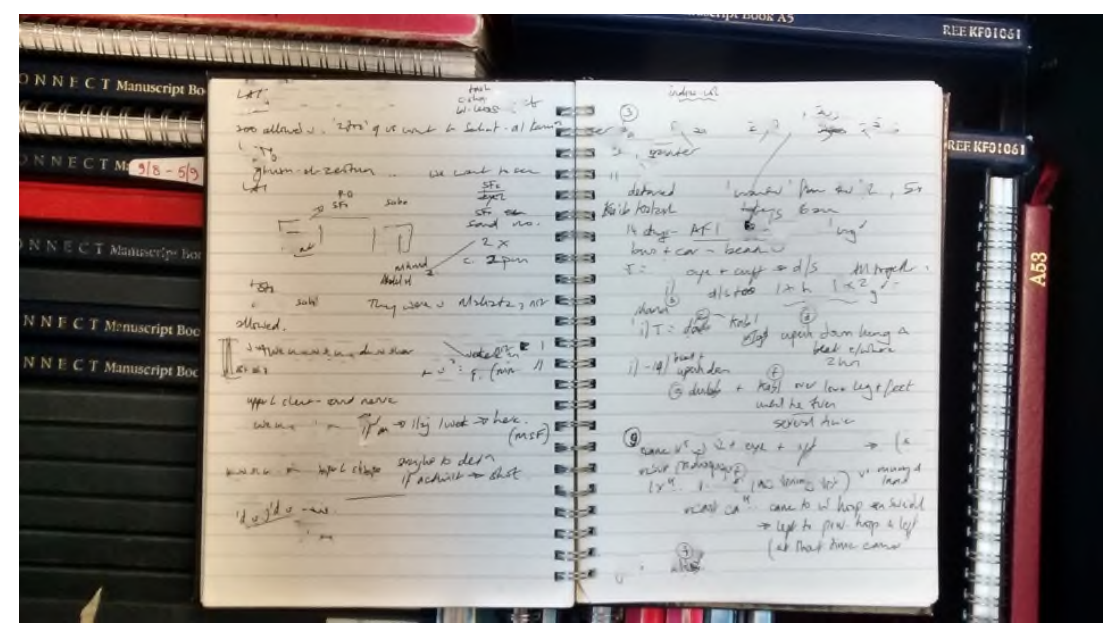

Figure 2 Mission notes (photograph pixelated to preserve confidentiality)

In the interviews with me, the researchers all gave my questions serious consideration, but found it hard to look at their mission notebooks again: either because they had been destroyed (INT6), or filed away (INT1 and INT2), or because the matter was difficult to re-open (INT3, INT4 and INT5; one MENA researcher who was approached for an interview felt compelled to refuse because looking at the notebooks would have been 'unbearable'), even though the task, now, was to look at the material for a different - academic and linguistic - purpose. For some, that angle provided a sense of validation and relief (INT2, INT3 and INT4), or a sense of pride (INT1), by shining a different light on 'the books full of sad stuff' (INT5).

\section{Entextualising and archiving testimonies: reiterating the genre}

The notebooks gave material form to the research justification for being in the field, created a visual distinction between witnesses and researchers, and acted as (psychological) shields protecting from exposure to the testimony. The encounters with witnesses were sensory as well as intellectual and emotional experiences, and most of these elements - the smells, tastes, touches, and some of the sights apart from descriptions of locations, living conditions 
and of injuries relevant to the human rights violation, the range of emotional reactions excepting empathy, and most of the intellectual processes aside from verification of facts were factored out of the notes (INT6 and INTRes). If the filter were not applied, 'researchers [would] come back with pages of mission notes that do not make the case for a human rights violation' (INTRes). Experienced researchers therefore took fewer notes, and could devote the encounters to engaging with witnesses fully, and thinking about their cases intensively (INT3 and INT6). The presence of an interpreter who rephrased the witness's words earned additional time within the encounter to engage and think (INT2). The filtering of information was an expectation derived from the researchers' roles as human rights experts, which the witnesses relied on for their performance of the testimonial encounter. Both the witnesses and the researchers hoped that the latter's expertise could make a solid human rights case and cooperated to give and find the information that would serve that purpose. The notations summarising that information were the testimony's first translation, from spoken Arabic to multilingual written mode (see similar forms of translation reported in Bielsa \& Bassnett 2009: 127; and in Maryns 2006: 217-249).

At the end of the fieldwork day, or at the end of the research mission, the researchers typed up their mission notes into documents, and uploaded photos together with captions, in computer files that were securely accessible only to specific colleagues. The second translation of the testimonies - their digitalisation - made the genre framing more evident, giving them conventional first-person narrative structure in full sentences, by conversion from the third person partial phrases in the notes and by resorting to memory of the conversation when reliable (as reported by all interviewed researchers). Witness testimonies were set aside from other sources of evidence, usually by quotation marks or different font (all researchers). The entextualisation into testimonial form entailed the chronological ordering of the narrative (INT1 and INT5) and the omission of the traces of the researchers' presence in the witness encounter, such as questions asked, opinions stated, and other, evidentially irrelevant, observations (INT3 and INT4).

Particularly emotive quotes, or sections of the testimony that best summarised the human rights violation, were set aside by highlighting or foregrounding at the start of the casefile (INT1 and INT2), and these would be recorded in Arabic (INT1, INT3 and INT5). If the quote were unclear, it would be checked over the 'phone against the witness's own recollection, against the notes of other researchers present (INT6) or of the interpreter (INT2). If audio recordings of the field interviews were available - and in the practices 
depicted here, they were not - these could be consulted at this point for informational backup, but would not be listened to in their entirety for reasons of expediency (INTRes).

Casefiles were titled by date and location followed by subtitles listing applicable human rights violations (all researchers). One of the native Arabic speakers translated notes taken in a transcribed spoken variety of Arabic into MSA (INT1). The documents continued to present a mixture of Arabic and English similar to the notebooks, though some additional effort was made to ensure intelligibility due to the potential need to share these documents, albeit only among colleagues who also shared deep contextual knowledge, as opposed to the notebooks, which were never intended for sharing. These transformations were termed 'tidying up' (INT3).

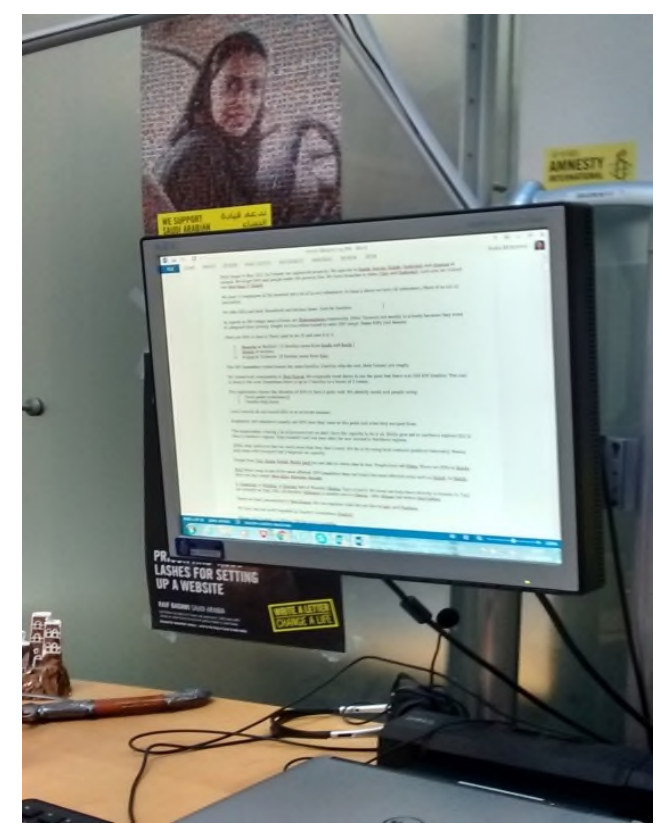

Figure 3 A typed-up casefile in the MENA Programme office

The digitalisation of mission notes was seen as an onerous bureaucratic task that placed high demands on the researchers' time and emotional effort (INT3, INT4, and INT5), and was of little practical value since in most cases only the researcher who wrote the documents would consult them (INT6), but was necessary for 'institutional memory' and 'the historical record' (INT1, INT2, INT6 and INTRes). This corresponded closely to the idea of the archive as a repository for collective social memory, 'maintained outside the human faculty of memory' (Schwartz \& Cook 2002: 6), and consequently Amnesty International's archived casefiles served a double purpose: to counteract any 'sanitised' archives that human rights violators might have wished to construct (INT1; and see Harris 2002: 135; Elsadda 2016), and to externalise in writing the emotionally burdensome memories of the researchers. In this 
context, the entextualisation of a testimony into its recognised genre's format was not perceived as requiring intellectual (as opposed to emotional) effort: it was 'simply' typing, and tidying up, in a self-evident way, of words responsibly co-created with the witness. The stability of the testimonial genre played a part in enabling the self-evident nature of the task: fitting the account of the violation into a first-person narrative, however traumatic, was a continuation of the ritual of the testimonial encounter.

\section{The publication of a testimony: orchestrated polyphony}

\subsection{Locking testimonies into persuasive formulations}

Ten to twenty per cent of the casefiles collected in Amnesty International's archive were published in reports, campaigning materials and media products (INT3, INT6 and INTRes). The first drafts of these texts were written, on behalf of the figurehead author 'Amnesty International', by the researchers and their closest team colleagues. The researchers selected which segment of a testimony, or which quotes from it, to include in the description of a case that instantiated a pattern of human rights violations (all researchers). Ellipses were inserted to indicate omitted text, with the aim of condensing narratives and avoiding repetitions (INT1, INT4 and INT6).

Researchers were given training and advice for writing reports, some of which was made explicit in the Guidance for staff on writing style and use of language, which stated that reports were primarily 'documents of (factual) record', but that the writers could make them 'compelling' by using 'story-telling techniques', of which individual cases and testimonies were the main component (Amnesty International 2017: 24). Testimonies were regularly spaced over the pages of a report (except in the chapters explaining legal obligations and listing recommendations to authorities), and some were accompanied by portrait photographs. Quotes from testimonies were used to introduce chapters. In contrast to the testimonies, which were rich in narrative and emotion, the descriptions and analyses of the rest of the text were 'dry', in accord with an inherited style of 'unflinching realism' (Wilson 1997: 149) that Amnesty International deliberately adopted as its authorial style in 1966 when it formulated the rule that its literature should 'avoid emotive or abusive expressions' (Hopgood 2006: 74).

The polyphonic cadence of alternating testimony with description, analysis and instruction matches the aspects of persuasive rhetoric pathos, logos and ethos (Lyon \& Olson 2011: 205). The orchestration of this polyphony was seen as essential for human rights researchers to convey their information skilfully (INT2, INT4 and INTRes). Persuasion of different 
audiences required varying emphasis on pathos, ethos or logos, with campaigning material, designed to support activists in applying public pressure, scoring especially high on pathos (INT6; Hopgood 2006: 75), and therefore on prominence of testimonies. All reports produced by the MENA Programme were written in English, and subsequently translated into Arabic, though shorter materials, such as those for online campaigns and media presentation were beginning to be written in Arabic by mid-2017 (INT6). Closest team members suggested English idiomatic phrases for testimonial quotes that 'sounded clunky' (INT6). At this point in the development of a publication, the formulations of testimonies became locked in place, safeguarded from the law and policy approvals process and copy-editing (INT2, INT6 and INTRes). The only admissible alterations to a testimony in a publication - its third 'translation' into publishable narrative in English - were abridgements (with ellipses) and graphic design.

\subsection{Contracting testimonies' professional translation: internal power relations}

So far in the trajectory of testimonies, presented here as a focus around which networks of agents were assembled, translations were undertaken by researchers who were not trained as translators. After the final expert approval of the documents written by the researchers, the documents and the testimonies in them were transferred for their fourth translation to the professional Arabic translation team at the Language Resource Centre that is a separate department from the MENA Programme. The analysis in sections (4.2-4.4) draws on an interview with two members of the Language Resource Centre, referred to as INTLang, as well as on information gathered in the MENA Programme, and on the textual analysis of MENA reports' translations into Arabic. Though the Language Resource Centre and the MENA Programme communicated both on the managerial level with regards to strategy and planning (INTLang, INT6) and on the production level with regards to specific terminology and phrasing (INT1, INT4), the relationship between the two parties replicated the dynamics of authors-clients and translators-contractors (Abdallah 2010: 15-16).

In addition to the power of authorship, researchers at Amnesty International carried weight in the organisation by virtue of their service, commitment to which other members of staff supposedly could not match (Hopgood 2006: 130-4); furthermore, in relation to the formulation of testimonies in particular, researchers wielded the advantage of having spoken to the witness themselves. The researchers, not the translators, were the 'reporters' of the testimonies' reported speech. The professional translators were relatively less structurally endowed with agency with regards to the texts, and therefore saw their task as 'careful' 
transmission that 'faithfully and accurately' preserved the Amnesty International message (INTLang; and see Tesseur 2015: 96, 109). Nevertheless, the translators controlled one aspect of the translation: the written style of Arabic documents.

\subsection{Translators' styles: channelling norms and designing audiences}

Style is a concept in linguistic anthropology that captures the performance of varieties of a language both in reference to the performer's socially patterned linguistic repertoire, and in reference to the expectations, or created expectations, of the audience, including of an imagined audience (Bell 2001; Bell \& Gibson 2011: 560), with little room for individual 'creativity and change' (Eckert 2004: 45). As seen above, the researchers' writing involved the polyphonic alternation of styles; how this polyphony came through in translation can be seen in the examination of MENA report titles that used quotes from testimonies and descriptive subtitles. ${ }^{4}$ The optimisation of a title's persuasive force would be particularly important since the title is disseminated as a free-standing slogan. The quote-title by necessity exhibits a condensed polyphonic style, analysed here as the juxtaposition of two styles: the testimonial and the formal 'dry' styles.

The testimony that is the source for the title "I wanted to die": Syria's torture survivors speak out, (أردت أن أموت": ضحايا التعذيب في سوريا يتحدثون عن محنتهم" [“aradtu 'an 'amūt”: ḍaḥāyā at-t'adīî fì sūriyā yataḥaddatūn 'an miḥnatihim]), is found on page 5 as 'I wanted to die', translated into Arabic as لقد أردت الموت 'I was desirous of death', said by Tarek to communicate the despair caused by being tortured..$^{5}$ In the recollection of the interview with Tarek, the researcher formulated the witness's probable spoken words as تمنّيت إني أموت [tmannēt inni 'amūt] 'I was hoping I'd die' (INT5). In written form, this could have been rendered as [نمنّيت أن أموت] tmannaytu 'an 'amūt, thus avoiding the formal أردت أن [aradtu 'an +verb] 'I wanted to [+verb]', and the excessively formal أردت أنس أ [+object]', and replacing it with a proximate lexical option in a style appropriate for the genre of testimony. ${ }^{6}$

\footnotetext{
${ }^{4}$ These reports, published 2012-2017, were located either by searching the www.amnesty.org website or thanks to references given by interviewees.

${ }^{5}$ Amnesty International, "I wanted to die": Syria's torture survivors speak out, https://www.amnesty.org/en/documents/mde24/016/2012/en/, published 14 March 2012, accessed 30 October 2016, p.5 in both English and Arabic versions.

6 كنا نتمنى الموت 6 [kunna nitmanna al-mawt] 'we were hoping for death' was expressed in testimonial style on p.27 of the Arabic version of another report on Syria: Amnesty International, Human slaughterhouse: Mass hangings and extermination at Saydnaya prison, Syria, https://www.amnesty.org/en/documents/mde24/5415/2017/en/, published 17 February 2017, accessed 5 March 2017.
} 
In other cases, testimonial quotes did not erase the social, expressive and communicative meanings (Halliday \& Hasan 2014: 22-26) of the spoken testimonial encounter that the quotes evoke. This was accomplished, for instance, in a quote from the report At any cost: The civilian catastrophe in West Mosul, Iraq: 'The cheapest thing in Iraq is a human being' "أرخص شيء في العر اق هو الإنسان" [arhaṣ šey’ fi l- 'irāq huwwa al-’insān], reported as said by Hashem, a resident of western Mosul. This quote was displayed prominently on campaigning materials: ${ }^{7}$ an example of their emphasis on pathos. The word order and the lexical choices of the quote correspond plausibly to a spoken Arabic equivalent that had been, presumably, instantiated in the testimonial encounter.

Negation morphemes in MSA, which is the stylistic norm for the written mode, are strongly marked by formality, as distinct from the spoken mode (connoted in the testimonial style), partly because the MSA negators are tense-inflected, while the spoken varieties of negators are not (Benmamoun et al. 2013). For quote-titles with grammatical negation, the polyphonic style therefore presented an additional challenge for translation into Arabic. The negation in the report title "I won't forget this carnage": Civilians trapped in the battle for Raqqa لن "lan ’ansa hadihi 1-madِbaḥa”: madanīyyūn muhāṣirūn fī m 'arakat ar-raqqa $]^{8}$ makes the style of the quote unambiguously formal. Formality is not the style of the corresponding English, which in the case of 'I won't' could have been formalised as 'I shall never'. This stylistic mismatch might not be possible to resolve without some relaxation of the norms of written Arabic, a relaxation that would allow to evoke the social, expressive and communicative meanings of speech in the testimonial encounter.

Both the testimonial quote and the descriptive subtitle in the Arabic titles were denoted flatly in the same, highly formal, style. The style of the Amnesty International Arabic translations were described as 'classicising' (INT6) and 'badly worded' (questionnaire comment, 2017) . The concept of 'style' would indicate that the translators were performing a variety of Arabic that indexed the social identities that they were trained to reiterate. In some translation traditions, 'media Arabic' (Ryding 2010) - whereby the MSA word order Verb-SubjectObject preference is relaxed and where calquing and borrowing from other (usually

\footnotetext{
${ }^{7}$ Amnesty International, At any cost: The civilian catastrophe in West Mosul, Iraq, https://www.amnesty.org/en/latest/campaigns/2017/07/at-any-cost-civilian-catastrophe-in-west-mosul-iraq/, published 11 July 2017, accessed 27 October 2017.

${ }^{8}$ Amnesty International, "I won't forget this carnage": Civilians trapped in the battle for Raqqa, https://www.amnesty.org/en/documents/mde24/6945/2017/en/, published on 23 August 2017, accessed 27 October 2017.
} 
European) languages is permissible, as it is in spoken Arabic - is warned against as an expression of anxiety about the dominance of English in the context of globalisation (Heller \& Duchêne 2007: 1-4; for the expression of such an Arabic translator's anxiety see Abdalla 2018). The Arabic translators have thus inherited diglossic norms (Eisele 2002) - which constrain the use of spoken varieties in certain functionally defined types of texts - and norms about the appropriateness of formal MSA styles in their profession. Language and translation norms are typical explanations for translators' choices (Koskinen 2010; Meylaerts 2008). However, generalised norms cannot account for engaging with polyphonic styles.

Style is also indicative of the audience towards which the translators orient themselves, or which they are designing (Mason 2000). In the MENA Programme staff questionnaire distributed in 2016 and 2017, the question 'What is the most important reason for translating Amnesty International documents into MENA languages?' elicited the response option 'To give Amnesty International legitimacy when advocating for MENA human rights' for 5 out of the 35 respondents, who thus prioritised the representation of Amnesty International in the eyes of governments and inter-governmental organisations; 10 chose 'To be accountable to stakeholders in the MENA region who contributed to the documents', which related to Amnesty International's relationship with local activists and witnesses; and 20 of the respondents (57\%) chose the option 'So that more people can read Amnesty International documents, ${ }^{9}$ indicating the majority of researchers' preference for an undifferentiated, general readership. On the other hand, the professional translators of the Language Resource Centre were beholden to the Amnesty International statute which emphasised communication with officialdom: 'The organisation aims to influence governments, intergovernmental organisations, armed political groups, companies and other non-state actors' (Tesseur 2015: 67-68), for which a formal style, especially of an arresting report title, might have been (normatively) considered paramount. We shall explore the receptivity of audiences in section (5.).

\subsection{Modifying testimonies: stretching the connection with witnesses for the persuasion of audiences}

If the audience of the Amnesty International reports were the witnesses who had been interviewed by the researchers, then the paradox of transferring testimonies co-produced in spoken varieties of Arabic to English, and from there translating them into formal MSA,

\footnotetext{
${ }^{9}$ There was a fourth option in response to the question - to write in the respondent's 'most important' reason for translation - but no one chose it.
} 
would be startling if the power-inflected agentic network were not taken into account. The text undergoing translation created a link between the witness, the researcher, the translators, and the audience. To make this link conscious, the 2006 edition of Amnesty International's Guidelines for Writers states that providing quotations in the original language is 'particularly important if you are using personal testimonies in Arabic, French or Spanish' (which are 'strategic' organisational languages; Tesseur 2015: 81, 106). The 2008 edition reads: 'where possible, provide quotations in the original language or give the reference for this. This is particularly important if you are using personal testimonies' (Amnesty International 2008: 12). This advice is meant to make translation practically straightforward, and prevent mistakes such as the translation into Arabic of the quote-title "No one can protect you": Bahrain's year of crushing dissent, as "لآ "لحد يسنطيع حمايتكم": عام من قمع المعارضة في البحرين 'aḥad yastațī' ḥimāyatakum”: 'ām min qim ə 1-mu āraḍa fì l-baḥrayn]. In 'protect you', the English personal pronoun object 'you' does not exhibit grammatical number, whereas himāyataKUM exhibits the second person PLURAL pronoun. The plural does not match the testimony presented in the report as Ebtisam al-Saegh's statement 'The men told me "no one can protect you"”, corresponding to the Arabic "قال لي الرجال "لا أحد يسنطيع حمايتك [qāl lī ar-riğāl "lā 'ahad yastațī' himāyataKI"] with the (correct) second person SINGULAR. ${ }^{10}$ The discrepancy in grammatical number of the personal pronouns can only be judged to be a mistake if one accepts without question that the quote-title must correspond verbatim to a testimony. When the quote was selected to form part of the title, that was because it had a broader, emblematic, and pathos-resonant, significance for the report and the subject that it drew attention to (INT2). With this function in mind, it would have been permissible to transform the testimony's singular pronoun into a plural for the title, thus encompassing all the unprotected dissenters of Bahrain (unmistakably in the plural) that the report mentions, despite stretching the supposedly direct link to the testimony.

The Guidelines' advice serves to portray translation as a 'transparent vehicle' (Spiessens \& Toremans 2016: 55), or in Amnesty International's case a 'transparent megaphone', transporting the testimony from 'the original' to the translated. This notion of transparency corresponds to a 'naïve model of communication' where mediation is considered neutral and objective (Baker 2010: 48). The mediated nature of the translation of testimony is apparent in examples of deliberately modified quotes used in titles (rather than accidentally, as in No one

\footnotetext{
${ }^{10}$ Amnesty International, "No one can protect you”: Bahrain's year of crushing dissent, https://www.amnesty.org/en/documents/mde11/6790/2017/en/, published 7 September 2017, accessed 21 September 2017, p.18 English version, p.20 Arabic version.
} 
can protect you). The modifications consciously sophisticate the evoked meanings to fit the emblematic function of the title.

In the case of Assaulted and accused: Sexual and gender-based violence in Tunisia, الاعتداء ثم [al-i 'tidā' tumma l-itihām: al- 'unf al-ğinsī wa l-qàa'im 'ala n-naw' al-iğtimā'i fì tūnis], the title was sourced to the protests sparked by the case of Meriem Ben Mohamed, who was charged with 'indecency' after she reported to the police that two police officers had raped her. According to the report's executive summary, " "raped and accused" became a phrase that highlighted the entrenched prejudices and discrimination against survivors of sexual and gender-based violence'. ${ }^{11}$ 'Assaulted and accused' and 'raped and accused' are nominalised adjectives that have the form of past participles which do not display, in English, grammatical gender. In Arabic, 'raped and accused' مغتصبة ومنهمة [mugtaṣiba wa mutahima] ${ }^{12}$ which are passive participles acting as nominalised adjectives, are presented in the feminine gender. The difference in grammatical gender inflection between English and Arabic meant that the reference to the testimonial and contextual meanings of the women's rights protests presented an intertextual opportunity and, concurrently, a grammatical problem. The emblematic function of the report's title dictated the broadening of the meaning to include all victims of sexual violence, whether they were women or men, and whether they had been raped or otherwise 'assaulted' (INT4). The cover of the report visually recognised the intertextual reference to the protests, as can be seen in Figure 4.

\footnotetext{
${ }^{11}$ Amnesty International, Assaulted and accused: Sexual and gender-based violence in Tunisia, https://www.amnesty.org/en/documents/mde30/2814/2015/en/, published 25 November 2015, accessed 30 October 2016, p.4 English version.

${ }^{12}$ Ibid., p.7 Arabic version.
} 


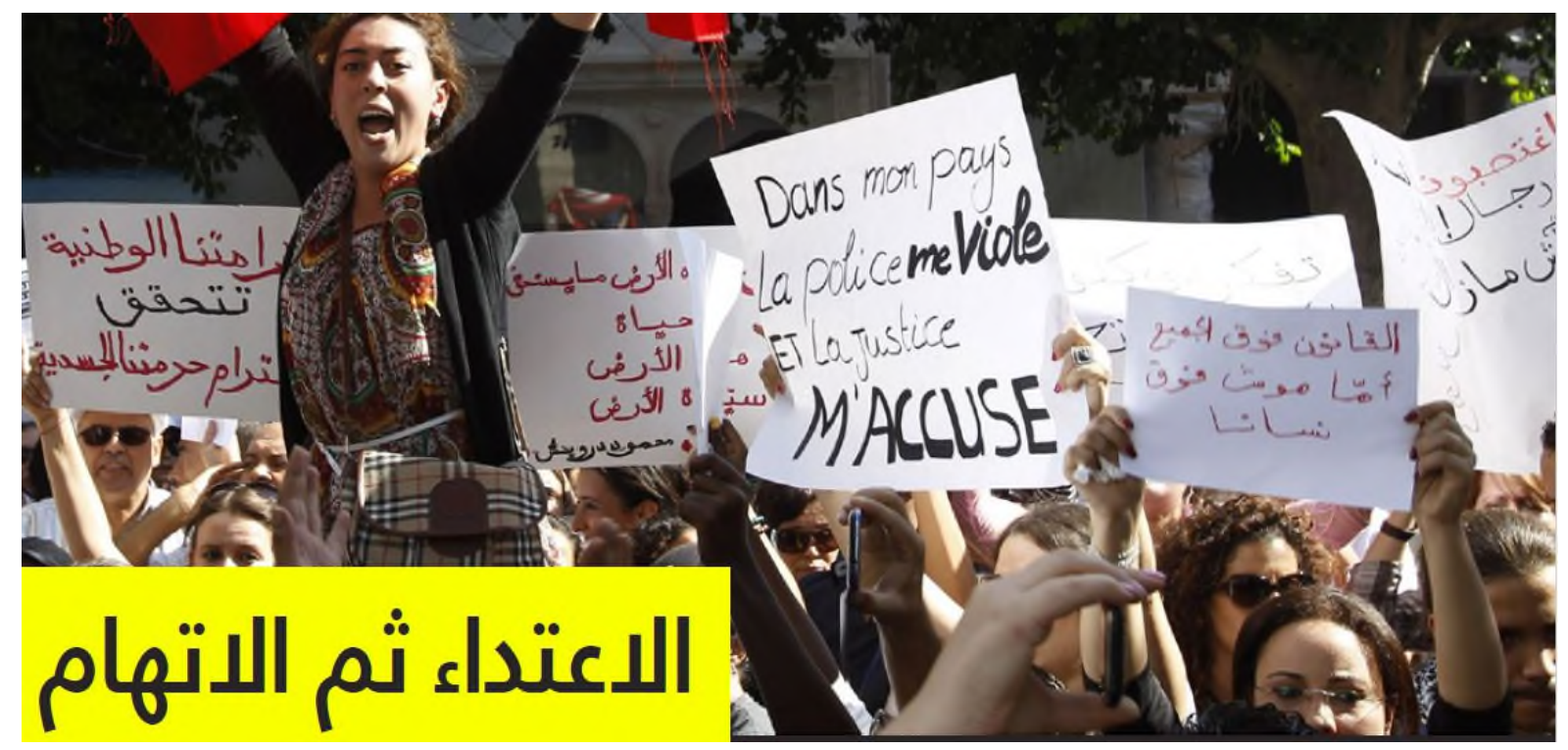

Figure 4 Part of the Arabic cover of the report 'Assaulted and accused'

The grammatical solution proposed by the Arabic title transformed the nominalised adjectives 'assaulted and accused' into verbal nouns, al-i 'tida ' tumma l-itihām, which literally translated back to English would stand as 'the assault then the accusation'. Gender inclusivity was formulated as gender neutrality (Pauwels 1998: 15) in the form of the verbal nouns which erased both the grammatical gender, as proxy for referential gender, and the passive voice; what was semantically lost, in comparison to the placards' مغتصبة ومتهمة [muġtașiba wa mutahima] was that it was a woman who had been raped and accused. This solution was a strategic campaigning choice because, while the Tunisian government had paid lip-service to strengthening provisions for the protection of heteronormatively positioned women, it refused to consider the rights of gays, lesbians, trans people (LGBTQ) and sex workers. The scope of the report included violations of the latter's human rights, inserted discreetly within the 'neutral' title (INT4).

The analysis of the fourth translation in the testimonies' trajectories - from written English, professionally, to written Arabic - uncovered further 'translations': from testimonial to formal style, from quoting to modified quoting. For testimonies, style is constrained by the genre-determined reference to the spoken testimonial encounter, entextualised as first person narrative and pathos, distinguished from the 'dry' and descriptive formal style of the rest of the text. This polyphony is developed in relation to audiences with certain expectations of Amnesty International's credibility and epistemic authority which the researchers and the translators textually perform for persuasive effect; conversely, the expectations of the 
audiences and the agency of Amnesty International are built into the textual form of the testimonies.

\section{Disseminating testimonies: reception in Arabic}

The analysis of this section of the article is based on results of three focus groups and an online survey conducted in 2017-8, which investigated reactions of Arabic speakers to receiving testimonies in specific Arabic varieties and styles. The hypothesis posited that some respondents might be especially unsympathetic to certain aspects of human rights and might be resistant to ideas of activism and solidarity if the manner of transmission of these aspects and ideas challenged sociolinguistic norms regarding the appropriateness of standardised writing and regionally differentiated, socially variable speaking of Arabic. The testimonies used in the experiments were drawn from the report Assaulted and accused: Sexual and gender-based violence in Tunisia referenced above. This was selected because violence against women happens in all countries, therefore the source of the testimony could not be guessed from the subject, but rather had to be inferred from the variety of Arabic in which it was conveyed. Each focus group received one testimony in a formal style of MSA (the text published by Amnesty International), one testimony in the urban Arabic of Tunis, and one in urban Palestinian Arabic. These were presented either as audio recordings performed by native Arabic-speaking actors using intuition to translate from MSA to dialectal Arabics, or as texts that transcribed those recordings: the fifth translations. The participants were warned prior to their consent that the content of the testimonies would be distressing.

\subsection{Witnessing in focus groups}

Focus group participants had uniform expectations of a testimony's (ideal) characteristics: it should be genuine (related to a real witness), authentic (conveying narratives and meanings that make emic sense to the witness), moving, and typical of a problem that is larger than the individual case.

In 'audio' focus groups in Britain and in Palestine, some participants (out of nine in total) expressed solidarity with the witness who spoke in their own variety of Arabic - one participant commented that it felt 'like being kicked in the gut' when they ${ }^{13}$ heard the North African dialect, and another that they 'couldn't help caring for Palestinians'. All agreed that the MSA recording sounded scripted, 'as if' the witness could have been 'a foreigner, an

\footnotetext{
${ }^{13}$ Since I am not undertaking a gendered analysis of the focus groups at this stage of the project, I am using the singular 'they' in this section.
} 
Arab, or anyone,' and then her testimony was 'presented on the news'. Some MSA lexical زجاجة من الجعة14 [zuğāğa min al-ği'a], stylistically equivalent to 'a draught of vintage'15, which contrasted with the testimony's picture of a drunken molester on the street corner, clutching a 'bottle of beer'. In both groups, towards the end of the conversation, one participant expressed their empathy with the witnesses while summarising the group's analysis and emotions, which they linked to personal experiences. This demanded great effort (similar to the engagement and thoughtfulness described in section (3.) above) and was applauded by the other participants: they had become witnesses to a witness of a (mediated) witness. I submit that the audience's reception of testimonies, when successful, is the final translation, with the potential to interpellate 'hearers' who can accept an otherwise silenced subject's knowledge without prejudice (Fricker 2007: 98).

The 'text' group that was focused on the written testimonies ran a different course: the participants (five people) were concerned about the professionalism and accuracy of the writing. The initial reaction to the MSA text was to ask whether it was a translation. There was strong divergence of opinion; one participant proposed that the optimal solution was to take away the quotation marks, convert the first person narrative to a descriptive text, and thus retain the formal MSA style, saying that 'it would be shocking to compromise on the style'. Two other participants suggested that the transcription of the spoken dialectal variety be retained in the testimonial form, but with square brackets inserted to explain basolectal items: 'We can't pretend that people don't speak like this.' One of them explained that their exposure, since finishing compulsory education in Arab schools, to 'more tolerant' ideas of the suitability of different language varieties, meant that the ideology of standardisation that they had grown up with had lost its hold. All were moved by the content of the testimonies, and this lead another participant to express the opinion that the testimonies would be equally poignant regardless of the style of writing, to which the other participants objected 'yes, but there are quotation marks'. There was no resolution to the discussion.

In both the 'audio' and the 'text' groups, I concluded by showing the cover of the report (reproduced in Figure 4) to reveal the source of the testimonies. One participant got tears in their eyes when they realised the discrepancy between the formulation of the protest placards and the title of the report (mentioned in section (4.4) above), stating that the title "is not

\footnotetext{
${ }^{14}$ Amnesty International, Assaulted and accused, as above, p. 44 Arabic version, p. 38 English version.

15 John Keats, Ode to a Nightingale (1819).
} 
connected to the people who said it. Amnesty ought to think about that.' Only one of the participants knew that the phrase النوع الاجتماعي [an-naw' al-iğtimā'î] meant 'gender' (for which they used جندر [ğandar]) and could define it. After some confusion, during which suggestions were made - 'is it to do with marital status? or sexual orientation?' - the other participants appreciated the correct explanation. In response to the ideologically-driven need, in all languages, to coin terms that match new thinking on social issues, Amnesty International publications and their translations play a role in formulating and spreading 'politically correct' terminology as part of its awareness-raising campaigns, as do many campaigning groups (Cameron 2005: 116-146). In line with Amnesty International's جندر translators' formal MSA style, as opposed to 'media Arabic' style, the loanword [ğandar] was not used in the published title. ${ }^{16}$

\subsection{Surveying regional commonalities and discords}

The online survey, completed by 150 anonymous respondents in Kuwait, Palestine and Tunisia, randomly assigned one of the three audio types (the same as were used in the focus groups) to respondents, and then asked questions about the testimony that captured feelings of solidarity, empathy, distrust and indifference. The respondent subsequently read the corresponding text, either in its MSA version, or in the transcribed dialectal variety, or in the transcribed dialect with explanatory brackets (as some in the 'text' group had suggested). The respondents were then asked questions about the accuracy, professional appearance, credibility, authenticity, and realism of the text, and its suitability for various purposes.

Poor intelligibility and sub-regional specificity were given as reasons for Amnesty International not using spoken or dialectal varieties of Arabic in its texts (INTLang, INT6). In the survey, the lowest score for intelligibility was given by one Palestinian respondent reporting to have understood $29 \%$ of the audio testimony in urban Tunisian; this respondent was nevertheless willing and able to accurately summarise the human rights violation in a comment box. The Tunisian respondents led in comprehension: $84 \%$ of them reported more than 50\% intelligibility for all the varieties. The Kuwaitis reported to understand the MSAspoken testimonies better than the other varieties (at least $80 \%$ for MSA compared to at least $40 \%$ for Palestinian and Tunisian varieties). Intelligibility of related varieties tends not to be mutual due to both linguistic and ideological perceptions of difference (Haugen 1966). The

\footnotetext{
النوع الاجتماعي [an-naw' al-iğtimāà î], lit. 'the social type', is itself a calque from the French 'le genre social'..
} 
asymmetric accommodation of North African speakers of Arabic to Middle Eastern speakers has been studied in sociolinguistics (Hachimi 2013).

With regards to the perceived functional suitability of the texts, the results were mixed. Of the $17 \%$ of all respondents who were highly supportive of using the testimonies for human rights campaigns, $52 \%$ had been allocated the MSA text, $24 \%$ the transcription of the dialectal variety with explanatory brackets, and $8 \%$ the transcription of the dialectal variety without brackets. The same respondents concurrently reported that it would be thoroughly unsuitable for the testimonies to be quoted in political speeches, whether in MSA or in dialectal varieties (an average 87/100 point score on suitability for human rights campaigns against an average $37 / 100$ for political speeches). Of the $9 \%$ of all respondents who were strongly opposed to using the testimonies for human rights campaigns, $50 \%$ had read the MSA text, $30 \%$ had been given the transcribed dialectal variety with explanatory brackets, and $23 \%$ had read the transcribed dialectal variety without brackets. They were also strongly opposed to other uses of the testimonies (2/100 points on suitability for political speeches), though some of the same respondents still accorded the testimonies relatively high scores for credibility and accuracy. It would seem that the Arab public, as represented in this survey, was highly skeptical of politicians' appropriating testimonial voices in their speeches, but most of them could countenance human rights campaigns based on testimonies in a range of Arabic varieties. Other researchers have also posited that the discursive functions of MSA and of other Arabic styles and varieties have been more multivalent in practices, which change, than the norms of diglossia have allowed for (Albirini 2016: 213).

What was striking in the focus groups and the survey responses was how well the Amnesty International testimonies worked qua testimonies, bearing in mind the journey described above that brought them to their audience: for the most part, they were recognised as valid testimonies, regardless of their mediated and decontextualised presentation in the experiments. (Only one of the actors who recorded the audio performance of the testimonies wondered at their precise chronology and logical pattern, whereby each woman diligently sought protection from the police despite the latter's hostility.) This provides evidence of the testimony genre's textual order and boundedness throughout the translations and mediations (Briggs and Bauman 1992: 147-149). Though the appropriate functions, the Arabic variety and the style were debated, the testimonies did most of the informative and pathos-resonant work that they were designed for, including creating the network that linked the witness, via 
the researcher, the translator, and the disseminator, to the audience (which, in the last lap, comprises the author and reader of this article).

\section{Conclusion: Translating for epistemic justice}

It is not the intention of this article to expose that under the cover of the megaphone lies a tortuous opaque game of 'Chinese whispers' (coincidentally named 'téléphone arabe' in French, and in Arabic تليفون مكسور 'broken telephone'). From the perspective of the social construction of meaning, the necessary partiality of mediation (Baker 2010; Kahane 2007), the different norms for spoken and written, English and Arabic texts, there could not be a verbatim 'accuracy' of a specific witness's utterance. People do not spontaneously speak in 'human rights testimony' formulations. Testimonies were always going to be co-produced and iterated, albeit under strict conditions of responsibility to the bounded genre and to the social, expressive and communicative meanings of the formative ritual encounter that the testimony evokes. Recognising the mediator's - whether the researcher or the translator's agency in bearing that ethical responsibility is what gives the publication of human rights testimonies the potential to redress testimonial injustice. This responsibility is captured textually, in the minutiae of style and the judgment exercised in modifying quotes: minutiae that are made salient in the process of translation.

The co-constructed meaning of the human rights testimony genre is qualitatively different from that of a statement to officials in authority, for instance in rape cases or asylum hearings, where interlocutors examine linguistic lacunae in testimonies in order to undermine their credibility (Ehrlich 2001; Maryns 2006); and is different from a historiographic project, where the recording of testimony involves the preservation of memories for their own sake and for inter-generational moral lessons (Hirsch \& Spitzer 2010). The testimonial type that most resembles the human rights testimony might be the deposition to truth and reconciliation commissions, where sites are created to make it safe and socially as well as individually beneficial to tell the truth (Gobodo-Madikizela 2006). Similarly to the experienced human rights researcher, an investigator in South Africa's Truth and Reconciliation Commission knew how, through a combination of engagement and thoughtfulness, to say the right words that allowed both witness and listener to exert 'immense effort and courage' by 'mentally holding on to each other' (Krog and Mpolweni 2016: 96). The human rights interviews and the commission hearings were ritualised as sites where witness and researcher cooperatively bore responsibility for the truthfulness of their words vis-à-vis a potentially hostile audience (Duranti 1993: 40-46). Experimental 
investigations into audience reception found that some Arabic speakers from different regions of MENA not only accepted the mediated presentation of testimonies in different varieties and styles of Arabic, but also exerted the effort and courage needed to take in the testimonies. The network linking witness and audience, via at least five translations, mostly succeeded.

Witnessing and expertise are power-differentiated constructs that were performed in the human rights interview rituals: that formative, though passing, occasion. At the forefront of the researchers' minds was the awareness that the exercise would be futile unless Amnesty International, institutionally, could position itself as testis to the witness's superstes. Testis is a third party in a lawsuit, who is 'neutral enough' to acquire facts for a trial, while superstes 'has experienced an event from beginning to end and can therefore bear witness to it' (Agamben 1999: 17). That this institutional positioning was also at the forefront of the witnesses' minds was only made explicit - as is often the case in conflictual interactions (Culpeper 2007: 23-30) - when a field research interview was difficult or impossible to perform, as reported by one researcher (INT3): the witnesses, who were mourning a child killed by the Israeli army in occupied Palestine, challenged the institutional ability and will of Amnesty International to bring any meaningful justice to the case, and therefore the value of cooperating with the interview, which was therefore not carried out. The researcher's personal commitment and skills were (reportedly) not questioned, but also not deemed relevant to the construction of the encounter. Though the researcher related the failure to 'bad timing' of this particular interview (and thus remediable in other cases), the account of the witnesses' objections also fits with reports of a certain Palestinian skepticism towards human rights organisations and their role in the political economy of the region (Allen 2013). The human rights interview had become meaningless - an empty ritual - in the context of Palestine where the social and individual benefit of performing the roles of superstes and testis was not in evidence.

Amnesty International iterates its 'neutral enough' role in its textual products, ${ }^{17}$ though explicitly on the side of respect for human rights; the testimony forms only one of several elements of a human rights case, the building of which includes critical examination of statements by political and military officials, of material and forensic evidence, ${ }^{18}$ and of

\footnotetext{
${ }^{17}$ The relative neutrality is contested by the governments that are criticised by Amnesty International (Cohen 1996), as well as being the object of internal struggles within the organisation (Hopgood 2006: 105-136; and see 'Amnesty International's existence "under threat"' www.bbc.co.uk/news/uk-england-london-20320623, published 14 November 2012, accessed 13 November 2017)

18 See the forensic methods of Citizen Evidence Lab, https://citizenevidence.org/, accessed 11 December 2017.
} 
reports by independent organisations and experts. When these evidential building blocks are in place, the testimony stands on a foundation: it provides, on the one hand, factual evidence of sufficient quality and quantity to raise the possibility of a lawsuit against the violators, and on the other hand an appeal to emotions that would convince engaged audiences, including the media, that the violations have intolerable human consequences. With this mission in mind, Amnesty International's researchers perform 'interviews' as a type of 'encounter', transform superstes into testis, and build 'evidence' from 'experience'. The testimony has to convey much of this work, by placing verifiable facts, reconstructed narratives, and extracts of utterances produced together with a genuine witness, into a recognised textual genre that is 'testimony'. Along the way, its translations happen unselfconsciously: the researchers saw this as their service, and Amnesty International's raison d'être.

The production-by-translation of testimonies is an evidential basis for thinking about the power dimensions of both translations and of testimonies. The analysis demonstrated the exchange of insights between linguistic anthropology and translation studies; linguistic anthropology could trace the emergence and resilience of a genre, which was described here as 'human rights testimony', within the causally modelled journey of translations. The linguistic-anthropological category of style, again incorporated into the causal model, could account both for norms which inform translators' choices and for the effects of these choices on audiences. In further inquiries it will be interesting to relate these findings to the commodification of the authenticity of testimonies and of the language and style of their entextualisation, both internally in organisations, contributing to the ethnography of institutions, and on the external stage of human rights politics, contributing to discourse analysis.

The megaphone does not exist. In place of that image, I present the trombone: it requires the thoughtful and sensitive engagement of hands, lungs and mouth to co-produce melodic tones, it adjusts its pitch according to the tenor of the contextual instruments, and its successful performance depends on its player's responsible practice.

\section{References}

Agamben, Giorgio (1999). Remnants of Auschwitz: The witness and the archive. New York: Zone books. 
Abdalla, Mohamed Siddig (2018). The Influence of Translation on the Arabic Language: English Idioms in Arabic Satellite TV Stations. Newcastle unpon Tyne: Cambridge Scholars Publishing.

Abdallah, Kristiina (2010). Translators' agency in production networks. In Translators' Agency (Tampere Studies in Language, Translation and Culture), Tuija Kinnunen and Kaisa Koskinen (eds), 11-46. Tampere: Tampere University Press.

Albirini, Abdulkafi (2016). Modern Arabic Sociolinguistics: Diglossia, variation, codeswitching, attitudes and identity. Abingdon/New York: Routledge.

Allen, Lori (2013). The rise and fall of human rights: Cynicism and politics in occupied Palestine. Stanford: Stanford University Press.

Andrews, Molly (2014). Beyond narrative: the shape of traumatic testimony. In We shall bear witness: Life narratives and human rights, Jensen, Meg, and Margaretta Jolly (eds), 32-47. Madison/London: University of Wisconsin Press.

Amnesty International (2008). Guidelines for writers. London: Amnesty International Ltd. Amnesty International (2017). Writing for Amnesty International - Guidance for staff on writing style and use of language. London: Amnesty International Ltd.

Baker, Mona (2010). Narrating the world: ‘Accurate' translations, suspicious frames. In Translating Justice - Traducir la Justicia, Araguás, Icíar Alonso, Jesús Baigorri Jalón and Helen J.L. Campbell (eds), 47-60. Granada: Editorial Comares.

Bell, Allan (2001). Back in style: reworking audience design. In Style and sociolinguistic variation, Eckert, Penelope, and John R. Rickford (eds), 139-169.

Bell, Allan, and Andy Gibson (2011). Staging language: An introduction to the sociolinguistics of performance. Journal of Sociolinguistics 15:5, 555-572.

Benmamoun, Elabbas, Mahmoud Abunasser, Rania Al-Sabbagh, Abdelaadim Bidaoui, and Dana Shalash (2013). The location of sentential negation in Arabic varieties. Brill's Journal of Afroasiatic Languages and Linguistics 5:1, 83-116.

Bielsa, Esperança, and Susan Bassnett (2009). Translation and global news. London/New York: Routledge.

Briggs, Charles L., and Richard Bauman (1992). Genre, intertextuality, and social power. Journal of linguistic anthropology 2:2, 131-172.

Cameron, Deborah (2005). Verbal hygiene. Abingdon: Routledge.

Chesterman, Andrew (2014). A causal model for translation studies. In Intercultural Faultlines: Research Models in Translation Studies Vol.1: Textual and cognitive 
aspects (second edition), Olohan, Maeve (ed.), 15-28. Abingdon/New York:

Routledge.

Cohen, Stanley (1996). Government Responses to Human Rights Reports: Claims, Denials, and Counterclaims. Human Rights Quarterly 18:3, 517-543.

Crystal, David (2003). English as a global language (Second edition). Cambridge/New York: Cambridge University Press.

Culpeper, Jonathan (2007). Reflections on impoliteness, relational work and power. In Impoliteness in Language, Bousfield, Derek, and Miriam Locher (eds), 22-53. Berlin: Mouton de Gruyter.

Duranti, Alessandro (1993). Intentions, self and responsibility: an essay in Samoan ethnopragmatics. In Responsibility and evidence in oral discourse, Hill, Jane H., and Judith T. Irvine (eds), 24-47. Cambridge: Cambridge University Press.

Eckert, Penelope (2004). The meaning of style. Texas Linguistic Forum 47, 41-53.

Ehrlich, Susan (2001). Representing rape: Language and sexual consent. London/New York: Routledge.

Eisele, John C. (2002). Approaching Diglossia: Authorities, Values and Representations. In Language Contact and Language Conflict in Arabic, Rouchdy, Aleya (ed.), 3-23. Abingdon/New York: Routledge.

Elsadda, Hoda (2016). An Archive of Hope: Translating Memories of Revolution. In Translating Dissent: Voices from and with the Egyptian Revolution, Baker, Mona (ed.), 148-160. London/New York: Routledge.

Felman, Shoshana, and Dori Laub (1992). Testimony: Crises of witnessing in literature, psychoanalysis, and history. New York: Routledge.

Fricker, Miranda (2007) Epistemic injustice: Power and the ethics of knowing. Oxford: Oxford University Press.

Gobodo-Madikizela, Pumla (2006). Healing. In Truth and reconciliation in South Africa: 10 years on, Villa-Vicencio, Charles, and Fanie Du Toit (eds), 71-76. Claremont: David Philip.

Hachimi, Atiqa (2013). The Maghreb- Mashreq language ideology and the politics of identity in a globalized Arab world. Journal of Sociolinguistics 17:3, 269-296.

Halliday, M. A. K., and Ruqaiya Hasan (2014). Cohesion in English. Abingdon: Routledge. Harris, Verne (2002). The Archival Sliver: A Perspective on the Construction of Social Memory in Archives and the Transition from Apartheid to Democracy. In Refiguring 
the Archive, Hamilton C., Harris V., Taylor J., Pickover M., Reid G., Saleh R. (eds), 135-160. Dordrecht : Springer. DOI: 10.1007/978-94-010-0570-8_9.

Haugen, Einar (1966). Semicommunications: The language gap in Scandinavia. Sociological inquiry 36:2, 280-297.

Heller, Monica, and Alexandre Duchêne (eds) (2007). Discourses of endangerment: Ideologies and interest in the defense of languages. London/New York: Continuum.

Hirsch, Marianne, and Leo Spitzer (2010). The witness in the archive: Holocaust studies/Memory studies. In Memory: Histories, theories, debates, Radstone, Susannah, and Bill Schwarz (eds), 390-405. New York: Fordham University Press.

Hopgood, Stephen (2006). Keepers of the flame: understanding Amnesty International. Ithaca: Cornell University Press.

Jensen, Meg, and Margaretta Jolly (eds) (2014). We shall bear witness: Life narratives and human rights. Madison/London: University of Wisconsin Press.

Kahane, Eduardo (2007). Interpreters in conflict zones: The limits of neutrality. https://aiic.net/page/2691/, accessed 11 December 2017.

Koskinen, Kaisa (2010). Agency and causality: Towards explaining by mechanisms in translation studies. In Translators' Agency (Tampere Studies in Language, Translation and Culture), Tuija Kinnunen and Kaisa Koskinen (eds), 165-187. Tampere: Tampere University Press.

Krog, Antjie, and Nosisi Mpolweni (2016). Archived Voices: Refiguring three women's testimonies delivered to the South African Truth and Reconciliation Commission. In Translating testimony, Spiessens, Anneleen, and Tom Toremans (eds). Témoigner/Getuigen 123, 84-99.

Lyon, Arabella and Lester C. Olson (2011). Special Issue on Human Rights Rhetoric: Traditions of Testifying and Witnessing. Rhetoric Society Quarterly, 41:3, 203-212, DOI: 10.1080/02773945.2011.575321.

Maryns, Katrijn (2006). The asylum speaker: Language in the Belgian asylum procedure. Abingdon/New York: Routledge.

Mason, Ian (2000). Audience Design in Translating. The Translator, 6:1, 1-22, DOI: $10.1080 / 13556509.2000 .10799053$.

Meylaerts, Reine (2008). Translators and (their) norms: Towards a sociological construction of the individual. In Beyond descriptive translation studies: Investigations in homage to Gideon Toury, Pym, A., Shlesinger, M., and D. Simeoni (eds), 91-102. Amesterdam: Benjamins. 
Milroy, James, and Lesley Milroy (1985). Authority in Language: Investigating Language Prescription and Standardisation. Abingdon: Routledge.

Pauwels, Anne (1998). Women changing language. London/New York: Longman.

Ryding, Karin Christina (2010). Media Arabic as a regional standard. In Arabic and the Media: Linguistic analyses and applications, Bassiouney, Reem (ed.), 217-228. Leiden: Brill.

Schwartz Joan M. and Terry Cook (2002). Archives, Records, and Power: The Making of Modern Memory. Archival Science 2, 1-19.

Spiessens, Anneleen, and Tom Toremans (eds) (2016). Translating testimony. Témoigner/Getuigen 123, 49-155.

Spivak, Gayatri Chakravorty (1988). Can the subaltern speak? Reflections on the history of an idea. In Marxism and the Interpretation of Culture, Nelson, Cary, and Lawrence Grossberg (eds), 21-78. Urbana/Chicago: University of Illinois Press.

Tesseur, Wine (2015). Transformation through translation: translation policies at Amnesty International, $\mathrm{PhD}$ Thesis. Aston University.

Vestergaard, Anne (2008) Humanitarian branding and the media: The case of Amnesty International. Journal of Language and Politics 7:3, 471-493.

Wilson, Richard (1997). Representing human rights violations: social contexts and subjectivities. In Human rights, culture and context: Anthropological perspectives, Wilson, Richard (ed.). London: Pluto Press. 
Nancy Hawker

ORCID 0000-0002-0693-4045

“Oriental” Institute, Pusey Lane, Oxford, OX1 2LE, United Kingdom

nancy.hawker@orinst.ox.ac.uk 